\title{
SCOLIOTIC GROWTH IN CHILDREN WITH ACQUIRED PARAPLEGIA
}

\author{
By Dr Ulrich K. Banniza von Bazan and \\ Prof. Dr Volkmar PaEslack \\ Orthopedic University Hospital, Department for Paraplegics, Heidelberg, Germany
}

Abstract. II6 children under the age of 15 have been studied with regard to scoliosis, primary vertebral injury, neurological symptoms, prophylaxis and therapy.

Key word: Scoliosis; Paraplegic children.

\section{Introduction}

AsIDE from a kyphotic or lordotic deformity of the spine, the occurrence of scoliosis in paraplegic patients seen in our hospital usually leads to a considerable worsening of their condition, in particular through deterioration of the breathing, circulation, kidney and bladder function, impeded intestinal activity, and often, because of a fixed pelvic obliquity, leads to the danger of a decubitus ulcer of the skin.

As is well known, adults who have sustained paraplegia are much less affected by scoliosis than are children, who, following the onset of paraplegia, still have a period of growth remaining. Although not all paraplegic children develop a significant scoliosis, a considerable number of them do. Many authors have already discussed the pathophysiology of paralytic scoliosis. From the cases observed at the Department for Paraplegia of the Orthopedic Hospital, Heidelberg, we wish to present some statistical data.

\section{Materials}

Paraplegics have been treated at the Orthopedic Hospital, Heidelberg, for more than 30 years (Table I). However, it is only since the establishment of a separate department for paraplegics (Ludwig Guttmann Haus) that the number of in- and out-patient children has considerably increased. In addition, many paraplegics who are vocationally rehabilitated in the affiliated Kurt Lindemann Haus are treated medically in this department. Thus we see many patients who, as children, sustained paraplegia and received primary treatment elsewhere. The primary treatment received by these patients has been very heterogeneous. Nevertheless, an attempt has been made, based on the data, to formulate some statements about the development of scoliosis in paraplegic children.

The present study involves a total of I66 children who sustained paraplegia before the age of I5 (Table II). Children with congenital paralysis caused by myelomeningocele or another type of spinal dysraphism were not included. All children with previous scoliosis have also been excluded, particularly those with tuberculosis of the vertebral body. All of the I66 children had a normal spinal column before the onset of paraplegia. They were born between 1936 and I974, the earliest case being a patient who became paraplegic in 1938 (Table I). 
TABLE I

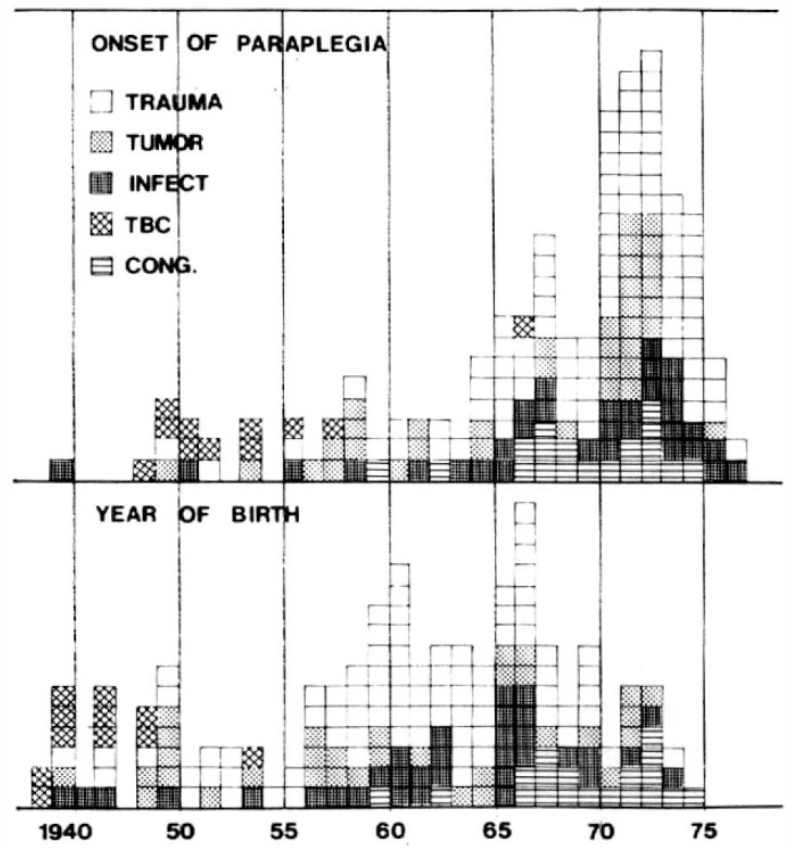

TABLE II

Paraplegia in childhood

\begin{tabular}{lr}
\hline Congenital, without spinal dysraphism & I9 \\
Infection & 32 \\
Tumour & 33 \\
Trauma & 82 \\
$\quad$ No spine fracture & 32 \\
$\quad$ With spine fracture & 50 \\
Spinal tuberculosis & I I \\
Pre-existent scoliosis & 4 \\
& \\
Total & I8I \\
\hline
\end{tabular}

As is evident from Table I, more than two-thirds of the patients came after the establishment of the special department for paraplegics, and approximately half (84) came in the five years between 1970 and 1974 . During the same time-period several hundred children with myelomeningocele have been treated in our hospital.

The 166 children included in this study are divided into three groups according to the age of onset of paraplegia (Table III). Eighteen children were born with paraplegia but with normal spinal X-rays. In one other case, because of perinatal asphyxia, a Tris-buffer had been infused into the umbilical artery which led to an incomplete lumbar paralysis. 
TABLE III

Age at onset of paraplegia

\begin{tabular}{|c|c|c|c|c|}
\hline & \multicolumn{3}{|c|}{ Years } & \multirow[b]{2}{*}{ Total } \\
\hline & $0-3$ & $3-8$ & $8-15$ & \\
\hline Congenital & 19 & - & - & 19 \\
\hline Infection & 8 & 6 & I8 & 32 \\
\hline Tumour & 8 & 7 & I8 & 33 \\
\hline \multicolumn{5}{|l|}{ Trauma } \\
\hline Spine fracture & 4 & 13 & 33 & 50 \\
\hline No fracture & 5 & I6 & II & 32 \\
\hline Total & & & & I66 \\
\hline
\end{tabular}

Thirty-two children were paralysed as a result of infectious disease of the spinal cord or its sheath. There were two cases of epidural abscess, two cases of $E$. coli meningitis, and one case of toxoplasmosis affecting the conus.

Thirty-three children became paraplegic as a result of a tumour, occasionally malignant, of the spinal cord or the vertebral canal. A laminectomy of one or more segments was performed in at least 24 of these children; II of these patients received in addition postoperative radiation. Two cases presented with syringomyelia, four with an intradural or intramedullary hemangioma; and in one case paraplegia resulted from an arachnoid cyst, and three others had bone tumours.

The largest group, about half of the children, were paralysed as a result of accidents. Of these accidents, $3 \mathrm{I}$ were traffic accidents, I 8 were falls, five were farm accidents, nine were gunshot wounds, nine diving accidents (all tetraplegics), and three were sports-related accidents. In small children who suffered traumatic paraplegia, there is often no radiologic evidence of any injury to the spinal column.

\section{Methods}

For purposes of this study we included only those cases in which there was suitable X-ray documentation. This left us with I 6 patients for this study. In some cases, the only available X-ray was a photograph of a portion of the spinal column taken originally from a pyelogram.

Only in the last four years has it become routine to take X-rays with axial traction applied and also in the sitting position (Fig. I). They are taken in the supine position only when the patient is unable to sit. The Cobb method of measurement is used. Scoliosis of less than $15^{\circ}$ was not considered significant enough to be included. The interval between the onset of paraplegia and the most recent X-ray was recorded.

The number of children who developed scoliosis is shown in Table IV. The cases were examined by classifying them according to the cause of paraplegia, the age of onset, the length of follow-up, and the level of the paralysis. In order to be able to formulate an unequivocal statement, those cases (especially children with cervical paralysis) in which the paralysis regressed to the extent that the patient was able to walk alone, without help from supporting caliper and crutches, were not considered. There remained a total of I 6 patients for this study. 


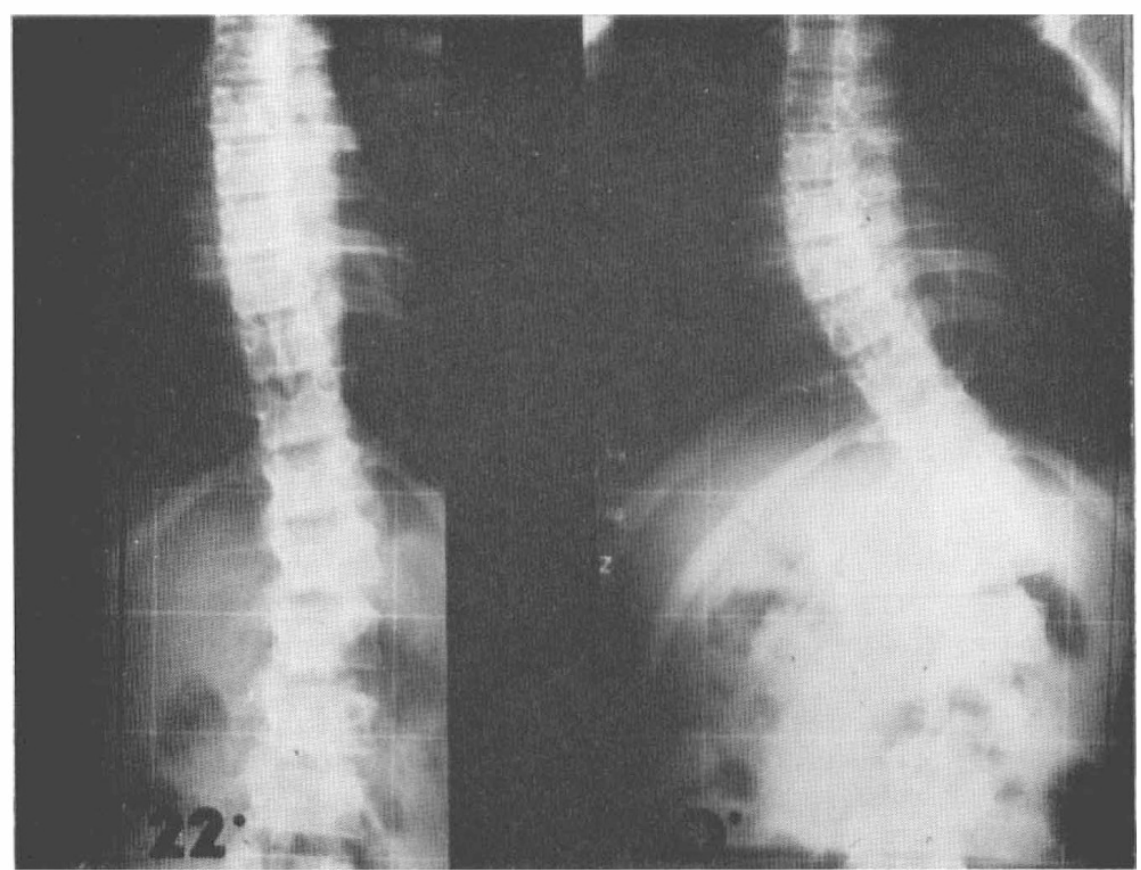

FIG. I

TABLE IV

I 6 Paraplegic children

\begin{tabular}{|c|c|c|c|c|c|}
\hline & \multicolumn{2}{|c|}{ No scoliosis } & \multicolumn{3}{|c|}{ Scoliosis $>15^{\circ} \mathrm{Cobb}$} \\
\hline & $n$ & $\begin{array}{l}\text { Spine X-ray } \\
\text { after yr;mo }\end{array}$ & $n$ & $\begin{array}{l}\text { Spine X-ray } \\
\text { after yr;mo }\end{array}$ & ${ }^{\circ} \mathrm{Cobb}$ \\
\hline Io Congenital & 7 & $4 ; 3$ & $3(30 \%)$ & $5 ; \mathrm{I}$ & 35 \\
\hline 20 Infection & 7 & $2 ; 10$ & $13(65 \%)$ & $6 ; 3$ & $39 \cdot 5$ \\
\hline 23 Tumour & 9 & $5 ; 8$ & $14(61 \%)$ & $4 ; 2$ & $4 \mathrm{I} \cdot 5$ \\
\hline 63 Trauma & 34 & $3 ; 3$ & $29(46 \%)$ & $4 ; 8$ & $3 I$ \\
\hline No fracture & 22 & $2 ; 3$ & I7 & 3;10 & 33 \\
\hline$\overline{\mathrm{c}}$ fracture & I 2 & $5 ; \mathrm{I}$ & 12 & $4 ; 8$ & $3 I$ \\
\hline
\end{tabular}

\section{Results}

Table IV shows the incidence of scoliosis in these groups and at the same time shows the average follow-up. Of the group who sustained paraplegia following infections of the spinal cord or spinal sheath, 65 per cent developed scoliosis. This was followed by the group with tumour-related paralysis, of whom 6I per cent developed scoliosis. Children with congenital paraplegia developed a significant scoliosis least often ( 30 per cent). The group with traumatic paraplegia lies approximately in the middle with 46 per cent having developed scoliosis. The most severe curves followed infectious or tumour-related paralysis. 


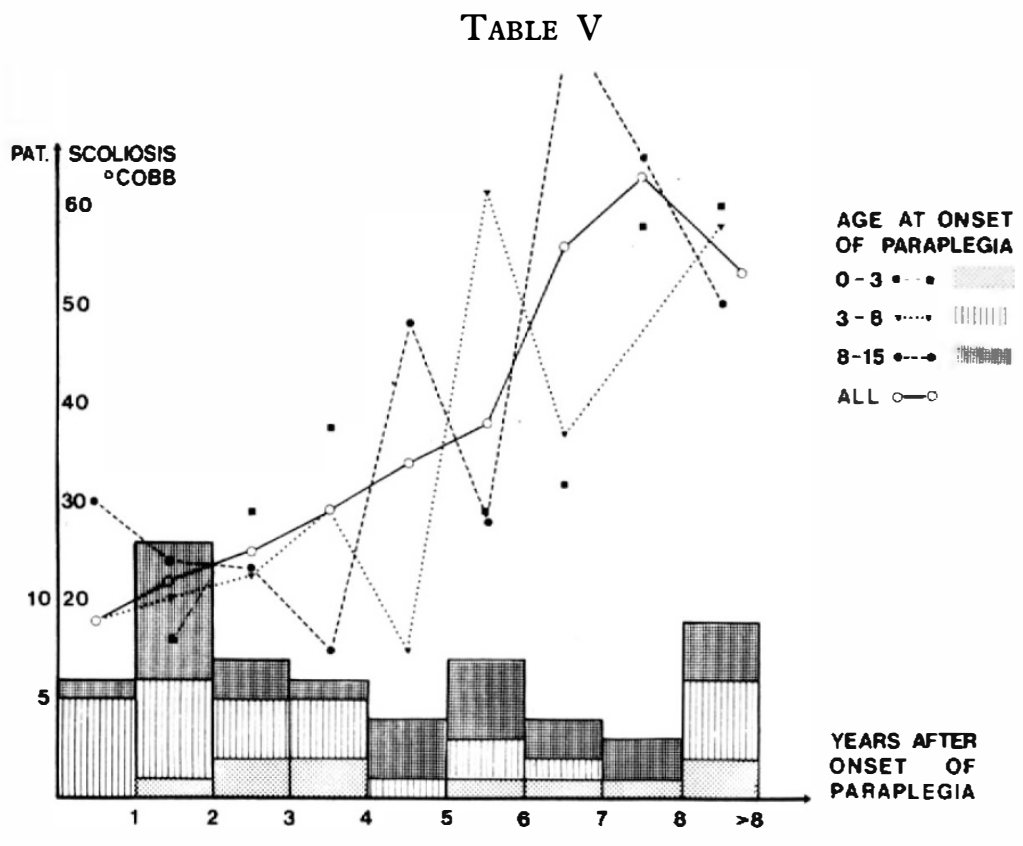

Table V contains a synopsis of all children in whom scoliosis of more than $15^{\circ}$ developed. The severity of the scoliosis is shown on the ordinate. All children, divided into three groups according to age of onset and length of follow-up, are presented on the abscissa. If serial X-rays were available, only the last one was used. Thus, each case occurs only once.

For each of the three age-groups the average degree of scoliosis is indicated and connected by an appropriate line. Whereas the curves of the individual agegroups are saw-toothed, the black line representing the total group shows a steady increase in the severity of the scoliosis with increasing survival time following the onset of the paraplegia.

\section{Discussion}

From this study we have demonstrated that the severity of the scoliosis increases with increasing length of follow-up. We should therefore assume, that the most severe scoliosis would be found in children who are paraplegic since their first years of life. At first glance Table VI gives no support to this theory. The incidence of scoliosis is highest in the 3 to 8 years group. The incidence in the zero to 3 years group is significantly lower. We must keep in mind, however, that the 24 children in this group are now an average of 5 years of age. The 36 children in the 3 to 8 years group are now an average of Io years of age. Many of these children are now adolescents. However, it is in this adolescent age-group where one would expect to see idiopathic scoliosis at its worst. Our infant paraplegics have yet to reach adolescence, and the prognosis for this group will probably be very bad.

Frequently an injury to the spinal column is seen as the primary cause of the developing scoliosis. This viewpoint would represent a satisfactory explanation 
TABLE VI

Age at onset of paraplegia

\begin{tabular}{lcccc}
\hline & \multicolumn{3}{c}{ Years } & \\
& $0-3$ & $3-8$ & $8-15$ & Total \\
\hline$n$ & 24 & 36 & 56 & II6 \\
No scoliosis & I3 & I3 & 3 I & 57 \\
Scoliosis $>$ I 5 & II & 23 & 25 & 59 \\
$\%$ & 46 & 64 & 45 & 5 I \\
\hline
\end{tabular}

for scoliosis following traumatic paraplegia. A vertebral body destroyed by tumour will also become the basis of scoliosis. Usually however, as you know, a kyphosis will result as in tuberculosis of the vertebral body. In these cases the kyphosis precedes the paralysis. On the other hand, it is generally agreed that a laminectomy, as is performed for tumour of the spinal cord, is followed by severe instability of the vertebral column which together with kyphosis can also lead to scoliosis.

Of the 22 tumour-affected paraplegic children that were laminectomised, nine are known to have received postoperative radiation (Table VII). The data does not support the idea that radiation played an important role in the development of the scoliosis.

Excessive elongation of the spinal column through birth trauma is also assumed when a paraplegic child is born without discernible vertebral or spinal malformation. The frequent breech presentation of these children is referred to as proof.

TABLE VII

Paraplegia following tumour

\begin{tabular}{lcc}
\hline & Scoliosis & $\begin{array}{c}\text { No } \\
\text { scoliosis }\end{array}$ \\
\hline Radiation & 6 & 3 \\
No radiation & 8 & 5 \\
Total & I4 & 8 \\
\hline
\end{tabular}

TABLE VIII

Congenital paraplegia and birth presentation

\begin{tabular}{lr}
\hline Unknown & 5 \\
Breech & 6 \\
Incomplete breech & 4 \\
Transverse & I \\
Cephalic & 2 \\
Total & I8 \\
\hline
\end{tabular}


TABLE IX

Myelomeningocele and birth presentation

\begin{tabular}{lr}
\hline $\begin{array}{l}\text { Cephalic } \\
\text { Breech }\end{array}$ & 2II \\
$64=24 \%$ \\
Total & 275 \\
\hline
\end{tabular}

Of the I 8 children with congenital paraplegia the birth position of five is not known and only two were born with cephalic presentation (Table VIII). Six breech presentations of which one was a twin, four incomplete breech presentations and one transverse presentation indicate at first glance a birth-traumatic elongation of the vertebral column with subsequent paraplegia. Nevertheless in our opinion it is more likely that the paraplegia was usually the cause of the breech presentation and not the opposite (Table IX).

\section{Conclusions}

The fact that paraplegia, caused by infection of the spinal cord or of its sheath, develops in 70 per cent of the cases to a scoliosis, speaks most clearly against a purely mechanical origin of the scoliosis. In our opinion the most important factor in the development of the scoliosis is the paralysis itself. Table X shows the cases with scoliosis on the left and with no scoliosis on the right. Each square symbolises one child, the shade indicating the etiology, the height indicating the last intact segment. The relation left to right is in the tetraplegics I I to I5, or 8 to 9, the walkers being excluded. In the thoracic levels, the ratio is 44 to 36 or 43 to 32 respectively, if the walkers are excluded. The incidence of scoliosis is obviously higher in the thoracic lesions than in the cervical. Along with other authors, McSweeney (1969) refers to the importance of the effect of imbalance of muscles that are not equally innervated from both sides. Roaf (1960) has stressed that asymmetrical action of the deep muscle fibres of erector trunci may well be one of

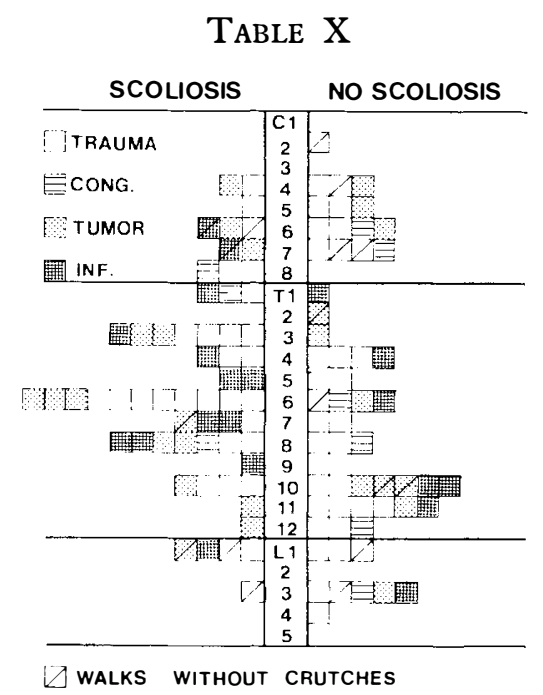

I $5 / \mathrm{I}-\mathrm{F}$ 
the important factors in initiating a rotational deformity of the vertebral bodies. We agree on the basis of our experience that particularly with thoracic paralysis a small asymmetry in the neurological level of paralysis, a difference in muscle tone or in spasticity plays a significant causative role in the onset of scoliosis. From observation of children undergoing remedial exercises we have the impression that such asymmetric paralysis occurs frequently. Objective proof for this hypothesis is not easy. Frequently the sensible level of paralysis does not coincide exactly with the motor level. Both are, however, important for the recovery of muscle tone and for the occurrence of spasticity over the spinal reflex arc. The level of motor paralysis can best be determined in the segments of the cervical and lumbar regions which are responsible for the innervation of the arms and legs. In the thoracic segments, the exact diagnosis of the level is difficult and can be objectively determined only with an electromyogram.

We would like to add to the discussion of the presented data a few concluding remarks based on our experience in the treatment of scoliosis (Figs. 2 and 3 ). It is agreed that treatment is best effected through prophylaxis of scoliosis. In addition to regular standing and gait training, therapeutic exercises or drug treatment of the spasticity should be carried out. We also try to hold the scoliosis in check through a spinal support. It is clear, however, that these attempts are only a compromise.

We perform a spinal fusion, which is recommended by some, only with considerable reluctance, because we fear an extensive loss of independence on the part of the children in their daily life activities. On the other hand, we would like to propose for the sake of discussion that in children with an early scoliosis and with proven asymmetric neurological level of paralysis, several thoracic segments

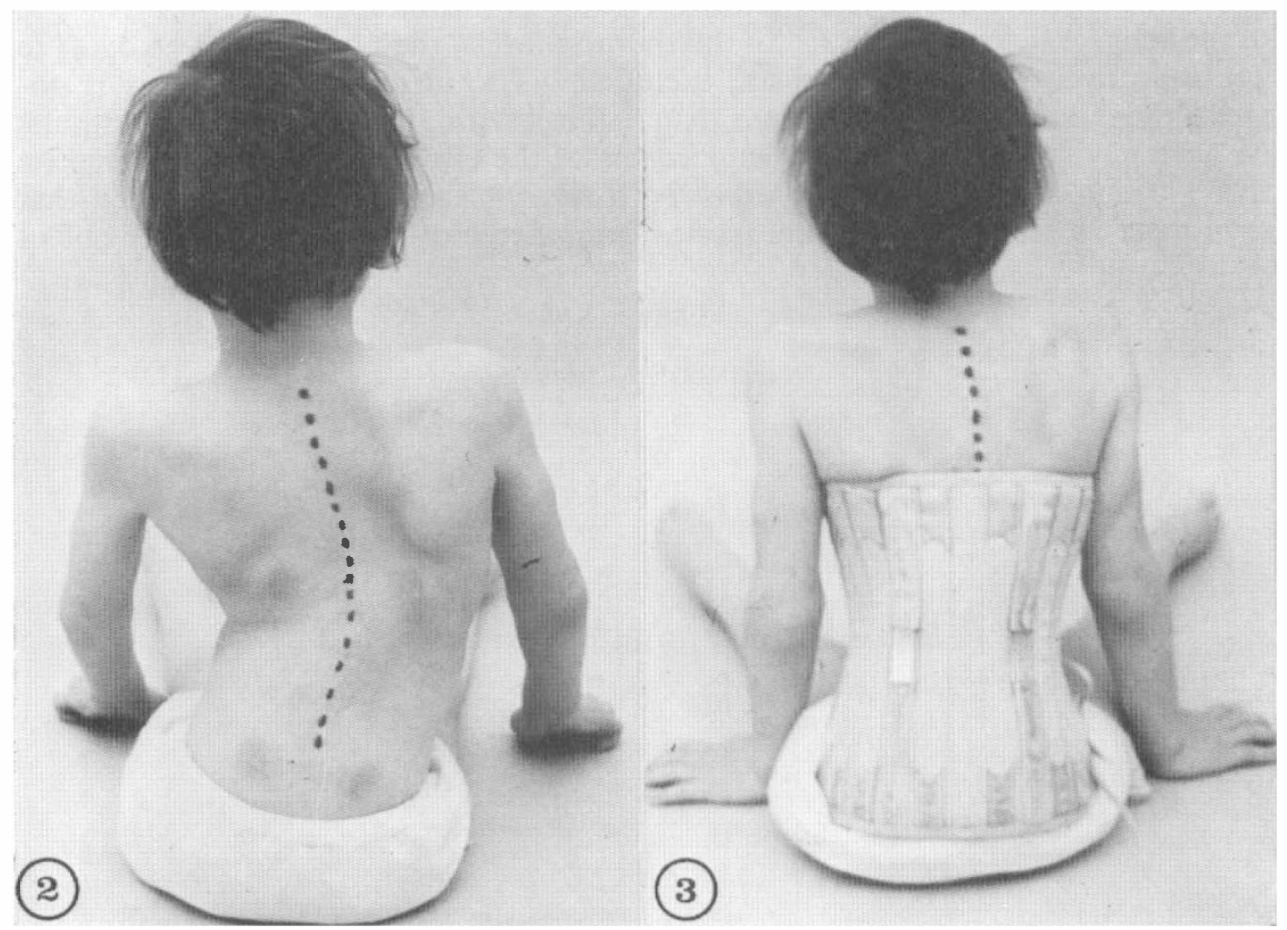

FIG. 2

FIG. 3 
should be knowingly sacrificed by a spinal nerve root transection, in order to produce the same level of paralysis on each side. We observed in one patient after rhizotomy for the purpose of eliminating pain, that simultaneously scoliosis improved from $45^{\circ}$ to $30^{\circ}$.

\section{SUMMARY}

I. I66 children with paraplegia occurring before the age of I 5 are presented, of whom I 6 are available for the study.

2. Scoliosis of more than $15^{\circ}$ developed in approximately one-half of the children.

3. Children with thoracic paralysis appear to be particularly endangered.

4. The primary spinal column injury as a result of an accident plays only a minor role in the development of scoliosis.

5. The asymmetric neurological level of paralysis is seen as a significant cause of scoliosis.

6. As prophylaxis, a spinal support as well as standing and walking exercises, including balance exercises, are recommended.

7. As possible therapy in cases with proven asymmetric neurological paralysis, rhizotomy of several thoracic spinal nerves may be discussed in order to achieve a balanced paralysis.

\section{RÉSUMÉ}

I. Rapport sur le cas de I66 enfants atteints de paraplégie avant l'âge de 15 ans, donc II6 ont été soumis à une contrevisite pour observer le développement d'une scoliose.

2. Chez environ la moitié des enfants une scoliose de plus de 15 degrés s'est développée.

3. Les enfants atteints de paralysie thoracique semblent spécialement menacés.

4. La lésion de la colonne vertébrale causée par un accident n'est que d'une importance secondaire pour le développement d'une scoliose.

5. Une assymétrie latérale de la paralysie est considerée comme cause principale favorisant le développement d'une scoliose.

6. Comme mesure de prophylaxie se recommendent un corset élastique ainsi que des exercises réguliers de marche et de balance.

7. Pour le cas évident d'assymétrie latérale de la paralysie on propose comme thérapie étant possible la rhizotomie (des racines) de quelques nerfs spinaux pour effectuer une symétrie latérale de la paralysie.

\section{ZUSAMMENFASSUNG}

I. Bericht über I66 Kinder, die vor Vollendung des I5. Lebensjahres querschnittgelähmt wurden, von denen II 6 bezüglich der Skoliosenentwicklung nachuntersucht werden konnten.

2. Bei etwa der Hälfte der Kinder entwickelte sich eine Skoliose von mehr als 15 Grad.

3. Kinder mit thorakaler Querschnittlähmung erscheinen besonders gefährdet.

4. Die unfallbedingte Wirbelsäulenverletzung selbst spielt für die Skoliosenentwicklung nur eine untergeordnete Rolle.

5. Als wesentliche Ursache für die Skoliosenentwicklung wird eine auf beiden Seiten unterschiedliche Lähmungshöhe angesehen.

6. Zur Prophylaxe werden ein elastisches Stützmieder sowie regelmäßige Steh- und Gehschulung und Balanceübungen empfohlen.

7. Als mögliche Therapie in Fällen erwiesener Seitendifferenz der Lähmungshöhe wird die Rhizotomie einiger Spinalnervenwurzeln vorgeschlagen, um eine seitengleiche Lähmungshöhe zu erreichen.

\section{REFERENCES}

McSweEney, T. (1969). Spinal deformity after spinal cord injury. Paraplegia, 6, 212-22I. RoAf, R. (I960). Vertebral growth and its mechanical control. F. Bone ft Surg. 42B, 40-59. 